\title{
Two-dimensional hydrodynamic modelling of channel processes and floods characteristics at the confluence of the Amur and Zeya rivers
}

\author{
Eugeniya Fingert $^{1,2}$, Inna Krylenko ${ }^{1,2}$, Vitaly Belikov ${ }^{2}$, Pavel Golovlyov ${ }^{1}$, Aleksandr Zavadskii ${ }^{1}$, and \\ Mikhail Samokhin ${ }^{1}$ \\ ${ }^{1}$ Faculty of Geography, Lomonosov Moscow State University, Moscow, 119991, Russia \\ ${ }^{2}$ Water Problems Institute, Russian Academy of Sciences, Moscow, 119333, Russia
}

Correspondence: Eugeniya Fingert (fingerte@gmail.com)

Published: 1 August 2019

\begin{abstract}
Two-dimensional hydrodynamic STREAM_2D model have been applied to the confluence of Amur and Zeya rivers. Main flow characteristics and possible channel changes are considered during modeling for two scenarios - without dams near Big Heihe Island (1) and with four dams in the side channels around the island (2). Results of modeling demonstrate impact of dams construction on flow concentrating in the main channel, which can lead to increasing of flow velocities and subsequent erosion in main Amur River channel downstream the river confluence.
\end{abstract}

\section{Introduction}

The confluence of the Amur and Zeya rivers is densely populated area. There are two main cities - Russian city Blagoveshchensk with 200000 residences on left bank of the river Amur and Chinese city Heihe with population over 1.5 billion residences on the right bank of the river. This territory is characterized by significant water problems related to floods and intensive channel processes. Last significant flood is affected Chinese and Russian citizens in the 2013 year, when the most part of floodplains, including many small settlements and the island Big Heihe were inundated (DanilovDanilyan et al., 2014; Bolgov et al., 2015). According to international legislations, the border between Russia and China is marked along channel thalweg, which position is continuously changing due to natural and anthropogenic drivers. In last 10 years, this area has attracted attention due to intensification of the hydrotechnical construction at the river confluence, including embankment of Blagoveshchensk and dams around the Big Heihe Island.

Modern studies for key area are based on the methods of hydrodynamic modeling. The influence of the Blagoveshchensk embankment on the channel processes have been investigated using two-dimensional model in
2011-2012 years (Belikov et al., 2012). The Chinese Institute of Water Resources and Hydropower Engineering (IWHR) has also developed models for this area. The further investigations of channel processes using two-dimensional hydrodynamic model were done based on novel bathymetric and floodplain topography datasets and also accounts dam allocation along channels around island Big Heihe (Krylenko et al., 2018). Both mentioned studies are identified, that embankment of Blagoveshchensk is affected on the flow only locally in the section of the Amur River above the confluence. The partial cutting of the secondary channels by the dams from the right bank of the Amur River can lead to the significant partitioning of water flow and increasing of erosion in the Amur River upstream and downstream from the confluence with the Zeya River.

Following with past experiments with two-dimensional hydrodynamic models (Belikov et al., 2012; Krylenko et al., 2018) hydrodynamic model 5 -year forecast of possible channel changes were performed and their influence on the evolution floods characteristics were estimated for two possible scenarios of river development: (1) without dams along channels around island Big Heihe and (2) under impacts of dams. 


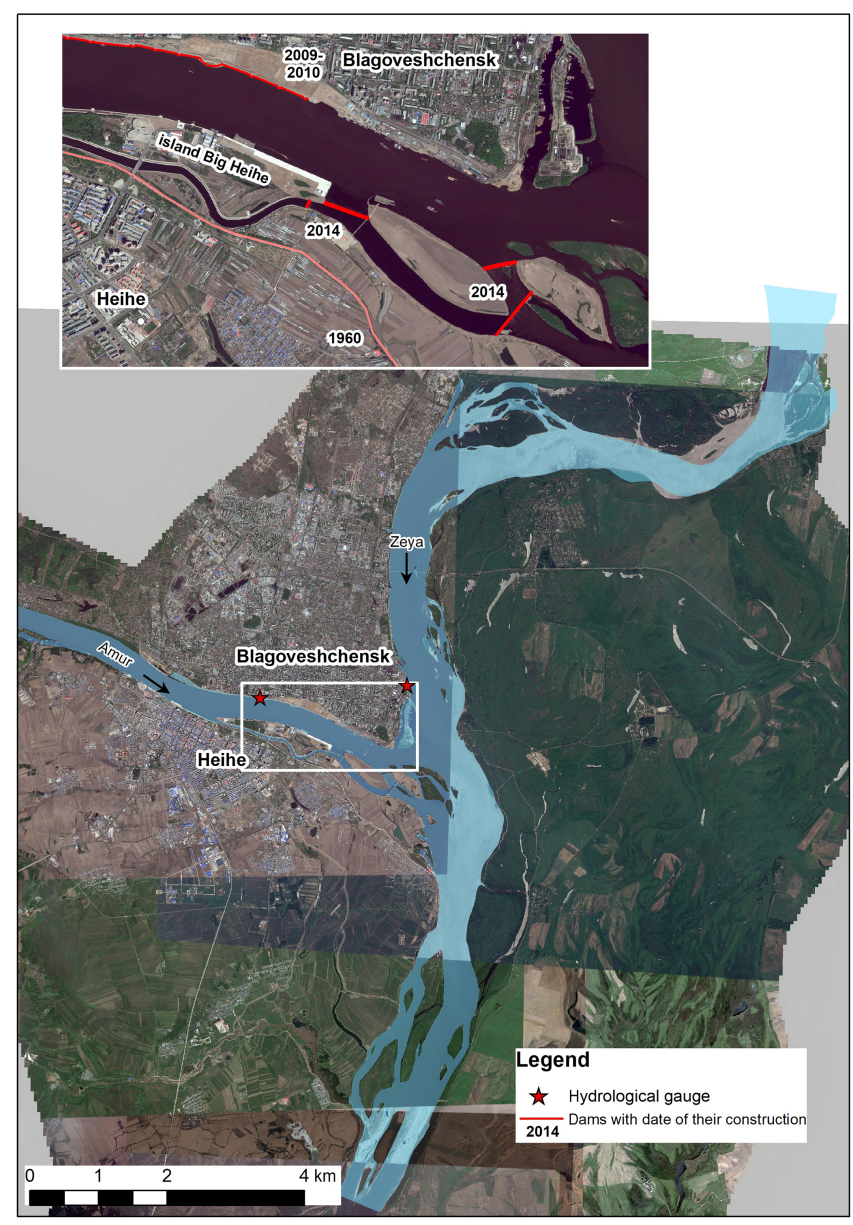

Figure 1. Study area.

\section{The study area}

The modeling area is included $15 \mathrm{~km}$ of the Amur River and $20 \mathrm{~km}$ of the Zeya River upstream from their confluence and $15 \mathrm{~km}$ of the Amur River downstream from the confluence (Fig. 1). The typical features of the Amur River channel are changing along its length. There is incised channel with many hard rock spots on the Amur River above the river confluence. Within Blagoveshchensk city Amur River channel is rectilinear, adapted along the left terrace bank, somewhere it is complicated by unilateral right-bank branches. Most of the urban area of Blagoveshchensk is located on the terrace above the floodplain. The opposite right bank, where the city Heihe is located, is characterized by the floodplains with the width about 5-6 km. The confluence of the Amur with the Zeya river have the complicated hydraulic conditions with backwater phenomena. Amur River has formed an inland delta with several islands near the right bank there. The Zeya River above the confluence as well as Amur River below the confluence is characterized by the wide floodplains with free conditions of the channel evolution.
The floods on these rivers are induced by the rains. The maximum water discharges of the Amur and the Zeya rivers at their confluence were observed in the August 1984, and were 16700 and $12800 \mathrm{~m}^{3} \mathrm{~s}^{-1}$, respectively. Recent extreme flood took place in the August 2013, maximum water discharges were 12288 and $13400 \mathrm{~m}^{3} \mathrm{~s}^{-1}$ correspondingly.

Both Blagoveshchensk and Heihe cities are protected from floods by the system of dams, constructed in the middle of 20th century. The embankment of Blagoveshchensk, which also has flood protective function as well as architecture value, is under construction from 2009-2010 years, and one of its section is not finished yet. The systems of dams around the Big Heihe Island is included four ground dams, blocking the flow in the small channels between islands from the Chinese riverside (Fig. 1). These constructions are look like ground cofferdams without any concrete reinforcements, the height of the dam's crest is the same, as the height of nearby floodplains (about $124.5 \mathrm{~m}$ a.s.l.), which means, that during high flow periods dams can be overflowed.

\section{Methods and data}

STREAM_2D software package, widely used in Russia (Belikov and Kochetkov, 2014), based on the numerical solution of two-dimensional Saint-Venant equations in the "shallow water" approximation using hybrid computational grids of irregular structure and original topography interpolation algorithms (Belikov and Semenov, 2000) was used for modeling. This model showed high efficiency in modeling both for flow hydraulics and channel deformations, including those for the rivers of the eastern region of Russia (Lena, Kolyma, Vilyuy, Yana, Amur) (Zaitsev et al., 2004; Belikov et al., 2002; Krylenko et al., 2018).

When modeling, a block of channel deformations was involved, taking into account the convective transport of soil particles by flow, soaking up and sedimentation of sediments in an uneven flow, changing the bottom levels over time, taking into account the effect of flattening (transverse diffusion) of the underwater slope in a direction orthogonal to the velocity vector. The description of the mathematical equations included in the numerical scheme of the model is presented, for example, in Belikov et al. (2015) and Aleksyuk and Belikov (2017).

The discretization of the modelling area in STREAM_2D was performed using an irregular hybrid computational mesh with more than 72 thousand cells. Curvilinear quadrangular grid was used for line structures; curvilinear triangular grid with a spatial resolution from $20 \times 30$ to $150 \times 200 \mathrm{~m}$ was adopted for the channels and floodplains.

Topography of floodplains, based on the highly detailed maps and bathymetry of river channels were used as the model input. The configuration of linear infrastructure including the dams from the Chinese side, the embankments of Blagoveshchensk, existing bridges and those under con- 
Table 1. Comparison of water levels for validation scenarios.

\begin{tabular}{|c|c|c|c|c|c|c|c|c|}
\hline \multirow{3}{*}{ Dates } & \multicolumn{2}{|c|}{$\begin{array}{l}\text { Input discharges of } \\
\text { the rivers }\left(\mathrm{m}^{3} \mathrm{~s}^{-1}\right)\end{array}$} & \multicolumn{6}{|c|}{$\begin{array}{l}\text { Water levels } \\
\text { (m a.s.l.) }\end{array}$} \\
\hline & & & Observed & Simulated & $\begin{array}{r}\text { Difference } \\
\text { between simulated } \\
\text { and observed } \\
\text { level, } \mathrm{cm}\end{array}$ & Observed & Simulated & $\begin{array}{r}\text { Difference } \\
\text { between modeled } \\
\text { and observed } \\
\text { level, cm }\end{array}$ \\
\hline & Amur & Zeya & \multicolumn{3}{|c|}{ Blagoveshchensk - Amur } & \multicolumn{3}{|c|}{ Blagoveshchensk - Zeya } \\
\hline 13 June 2018 (low flow) & 1510 & 1390 & 120.63 & 120.67 & 4 & 120.15 & 120.21 & 6 \\
\hline 18 July 2018 (rain flood) & 3500 & 7680 & 124.70 & 124.79 & 9 & 123.90 & 123.91 & 1 \\
\hline 16 August 2013 (extreme rain flood) & 12288 & 13400 & 128.10 & 128.21 & 11 & 127.93 & 127.92 & -1 \\
\hline 15 August 1984 (extreme rain flood) & 16700 & 12800 & 128.45 & 128.61 & 16 & 128.29 & 128.24 & -5 \\
\hline
\end{tabular}

struction, and the road embankments on the floodplain were taken into account in the model grid and topography. Several digital terrain models with bathymetry 2017 and 2018 years and different sets of engineering structures were prepared. New data was also supplemented with the results of 2011 field survey.

Data from hydrological statations Zeya-Belogorie, AmurKumara, and Amur-Grodekovo were used as the boundary conditions. The water levels at stations, located in the cities (Blagoveshchensk on the Amur and on the Zeya), were taken into account for the model calibration and validation. The data of engineering survey of 2017-2018, including the measured water discharges, and water surface slopes, were used for model development.

The average diameter of channel sediments $0.9 \mathrm{~mm}$ was taken in to account, the diameter of the $90 \%$-probability ( $90 \%$ of particles is less than $2.5 \mathrm{~mm}$ ) was set at $2.5 \mathrm{~mm}$ for the modeling. The position of the surface of clay sediments and rocky cliffs was defined according the geological survey data.

The simulation was carried out for a 5-year forecast period, daily hydrographs of the previous period 2011-2015 years were used as the boundary conditions. This period can be assumed as the most representative, because it is included the extreme flood period of the year 2013 as well as years with the average flow conditions.

\section{Model calibration and validation}

The initial model calibration and validation were performed using bathymetry data from the 2017 year and demonstrated good correspondence of modelled and observed water levels for different hydrological situations (Krylenko et al., 2018). On this step, validation of the model was carried out based on the data of engineering surveys of 2018 (Table 1). The model reproduces water level and flooding areas for all hydrological situations with channel and floodplain roughness coefficient of 0.020 and 0.050 , respectively; the differences between the simulated and observed water levels at Blagoveshchensk were less than $10 \mathrm{~cm}$.
An additional validation was carried out for the outstanding floods of 1984 and 2013 using riverbed bathymetry of 2018 surveys. On 15 August 1984, a flood of $1 \%$ exceedance probability took place near Blagoveshchensk; water levels at the station Amur-Blagoveshchensk came up to a maximum height of $868 \mathrm{~cm}$ (128.56 m a.s.l.), some streets of the city near the river were inundated. The recent extreme flood of 2013 was characterized by the long period of flooding in the entire Amur basin (Danilov-Danilyan et al., 2014; Bolgov et al., 2015). The maximum water level at the station Amur-Blagoveshchensk during this flood exceeded the height $822 \mathrm{~cm}$ above the station zero (128.10 ma.s.l.) on 16 August and the model reproduce this flood with the good accuracy, difference between modelled and observed water levels by the station Amur - Blagoveshchensk is $11 \mathrm{sm}$, by the station Zeya - Blagoveshchensk is $-5 \mathrm{sm}$. The additional analysis of the inundation zones was performed using satellite images Radarsat and Landsat, the difference between simulated and observed flooded areas was less than $10 \%$.

The comparison of modelled and observed channel changes was done on the previous step of research for the period 2011-2015 years and has showed, that the model captured location of the main erosion and deposition zones, as well as their amplitude (Krylenko et al., 2018).

\section{Results of scenario modelling and their discussion}

Results of estimations of water discharges redistributions has showed, that due to the dams construction in the side channels, flow will be concentrated in the main channel of the Amur River under discharges $1500-5500 \mathrm{~m}^{3} \mathrm{~s}^{-1}$, flow in the main channel will be increased up to $15 \%-20 \%$. As result, water levels in the main channel of the Amur River near Blagoveshchensk according scenario 2 will be higher on the $15-20 \mathrm{~cm}$ in comparison with scenario 1. During peak flow, dams will be overflowed and their influence on the discharges redistribution will be smaller. The water discharges in the main channel of the Amur River above the confluence during peak floods will be increased up to $5 \%-6 \%$, water levels 


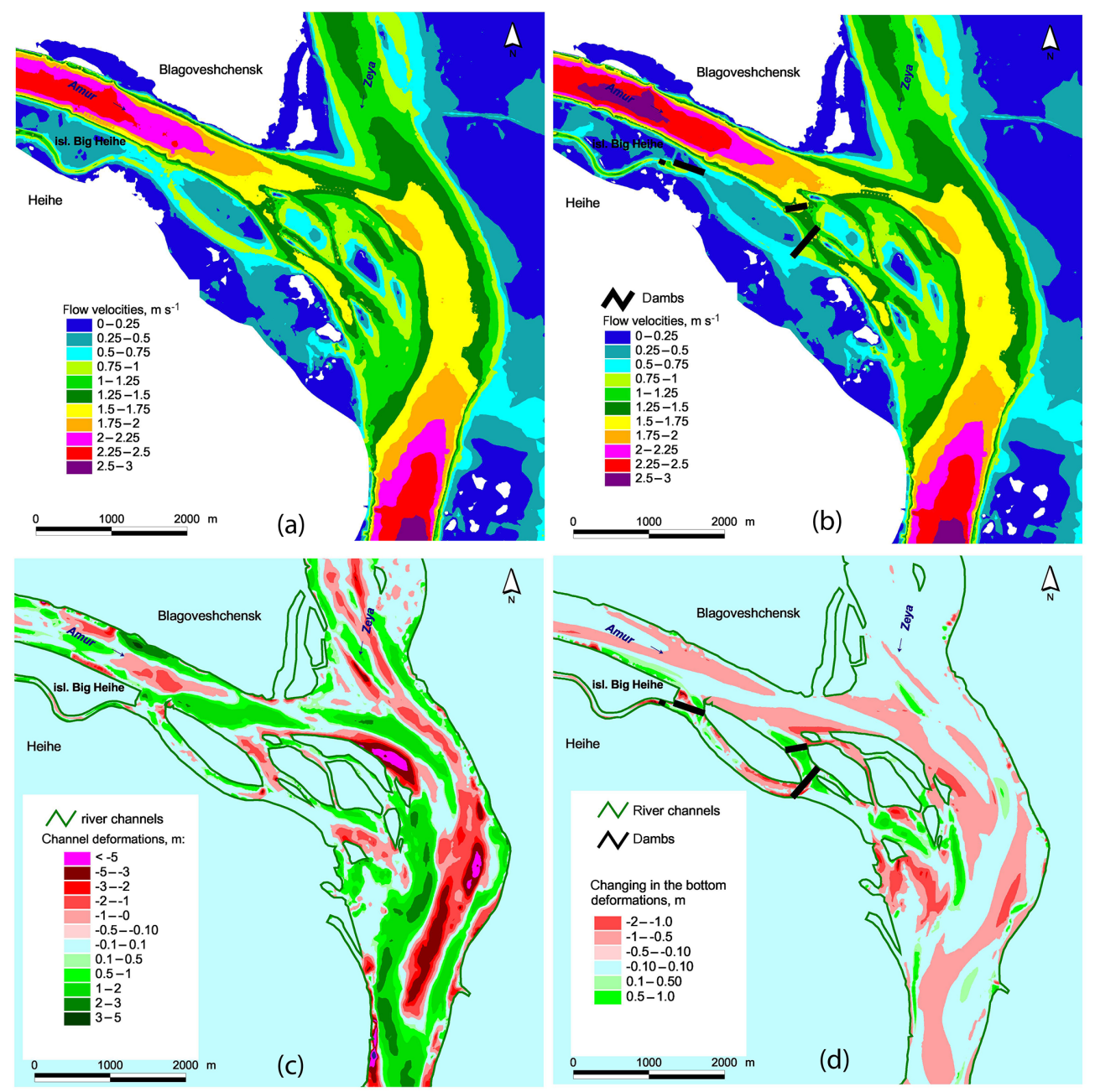

Figure 2. Modelled flow velosities during peak flow in the 2013 year according scenario 1 (a) and scenario 2 (b); modelled channel evolution at the confluence of the Amur and Zeya rivers for 5-year forecast period according scenario 1 (c), changes in channel bottom changes due to construction of dams (difference in changes between scenarios 2 and 1) (d).

- up to $10-15 \mathrm{~cm}$. The concentration of the water flow in the main channel will lead to the increasing of the flow velocities near the station Blagoveshchensk on to $0.15 \mathrm{~cm} \mathrm{~s}^{-1}$, and up to $0.35 \mathrm{~cm} \mathrm{~s}^{-1}$ downstream to the river confluence (Fig. 2).

The channel evolution analysis for the end of 5-year forecast period has showed that location of erosion and depositional areas in the river channels will be same as in the current period for the both scenarios. There are the main erosion zone at the Muraviev Island and in the area at the mainstream line of the Amur River downstream from the confluence and the deposition zone downstream the islands. However, due to the blocking of the side branches by the complex of dams, the erosion in the main channel of the Amur River will increase onto 1-1.5 m compared to the scenario (1) without the dams. Mainstream of the Amur River as well as the Russian Chinese boundary can shift by $50-70 \mathrm{~m}$ toward the left bank within a reach more than $1 \mathrm{~km}$ long downstream from the confluence (Fig. 2). The erosion in the main channel can lead to the lowering of the water levels in the end of 5-year forecast period on to about $10 \mathrm{~cm}$. As result the two processes - concentration of the flow in the main channel and channel erosion will be in similar conditions regarding water levels changes.

\section{Conclusions}

The two-dimensional hydrodynamic model of the important transboundary Russian-Chinese key area at the confluence of the Amur and Zeya rivers was developed based on STREAM_2D software. The model reproduces rather well all hydrological situations including extreme flood of 2013 year and captures the main features of channel processes.

The analysis of the possible influence of the dam construction along channels around the Big Heihe Island on the water flow and channel changes was done using scenario modeling approach. 
The comparison of flow characteristics for two scenarios without dams (1) and with dams (2) has showed that allocation of dams can lead to the increasing of water discharges, water levels and flow velocities in the main channel of the Amur River upstream the confluence. Analysis of channel changes at the end of 5-year forecast period demonstrated $1 \mathrm{~m}$ erosion increase at the main channel of the Amur River downstream from the confluence with the Zeya River according scenario (2). However, the water level growth will be less pronounced due to channel erosion, which causes that no significant changes in the flooding zones should be expected.

The further monitoring of situation in the confluence of the Amur and Zeya rivers including projects of constructions on the floodplains and in the channels should be proceed using developed model due to complex influence of natural and anthropogenic factors on the flow characteristics.

Data availability. Data available upon request to the contact author.

Author contributions. VB developed mathematical model, PG prepared digital terrain models, MS analyzed hydrological data, AZ developed experiment design and supervised the project, EF and IK performed the simulations and result analysis.

Competing interests. The authors declare that they have no conflict of interest.

Special issue statement. This article is part of the special issue "Land use and climate change impacts on erosion and sediment transport". It is a result of the ICCE Symposium 2018 - Climate Change Impacts on Sediment Dynamics: Measurement, Modelling and Management, Moscow, Russia, 27-31 August 2018.

Acknowledgements. The authors of the paper express their deep gratitude to the Laboratory of Soil Erosion and Channel Processes of the geographical faculty of Moscow State University and CJSC Lengiprorectrans for providing the field research materials.

Financial support. Analysis of the floods characteristics was supported by the Russian Foundation for Basic Research (grant RFBR no. 17-05-01230), the channel changes evaluation was supported by the Russian Science Foundation (grant RSF no. 18-1700086).

\section{References}

Aleksyuk, A. I. and Belikov, V. V.: Simulation of shallow water flow with areas and bottom discontinuities, Comp. Math. Math. Phys., 57, 318-339, https://doi.org/10.1134/s0965542517020026, 2017.

Belikov, V. V. and Kochetkov, V. V.: Software Complex STREAM_2D to Calculate Streams, Bottom Deformation, and Pollutants Transfer in Open Flows, Software State Registration Certificate no. 612181, Russian Agency for Intellectual Property, 2014.

Belikov, V. V. and Semenov, A. Yu.: Non-Sibsonian interpolation of arbitrary system of points in Euclidean space and adaptive isolines generation, Appl. Numer. Math., 32, 371-387, 2000.

Belikov, V. V., Glotko, A. V., Belousova, I. V., and Zavadsky, A. S.: Application of numerical hydrodynamic modelling for solving border water objects in Siberia, Barnaul: Fundamental'nyye problemy vody i vodnykh resursov [Barnaul: Basic Problems of Water and Water Resources], Water and ecological problems of Siberia and Central Asia, 1, 7-15, 2012 (in Russian).

Belikov, V. V., Krylenko, I. N., Alabyan, A. M., Sazonov, A. A., and Glotko, A. V.: Two-dimensional hydrodynamic flood modelling for populated valley areas of Russian rivers, Proc. IAHS, 370, 69-74, https://doi.org/10.5194/piahs-370-69-2015, 2015.

Bolgov, M. V., Alekseevski, N. I., Gartsman, B. I., Georgievski, V. Yu., Dugina, I. O., Kim, B. I., Makhinov, A. N., and Shalygin, A. L.: The 2013 extreme flood within the Amur basin: analysis of flood formation, assessments and recommendations, Geogr. Nat. Resour., 36, 225-234, 2015.

Danilov-Danilyan, V. I., Gelfan, A. N., Motovilov, Y. G., and Kalugin, A. S.: Disastrous flood of 2013 in the Amur basin: genesis, recurrence assessment, simulation results, Water Resour., 41, 115-125, https://doi.org/10.1134/S0097807814020055, 2014.

Krylenko, I., Belikov, V., Fingert, E., Golovlyov, P., Glotko, A., Zavadskii, A., Samokhin, M., and Borovkov, S.: Analysis of the impact of hydrotechnical construction on the Amur river near Blagoveshchensk and Heihe cities using a twodimensional hydrodynamic model, Water Resour., 45, 112-121, https://doi.org/10.1134/S0097807818050378, 2018.

Zaitsev, A. A., Belikov, V. V., and Militeev, A. N.: Using computer modeling for a large river, Proc. Int. Symp. "Sediment Transfer through the Fluvial System", Moscow, IAHS Publ. 288, ISBN 1-901502-67-8, 386-394, 2-6 August 2004. 